\title{
SOCIOLOGICAL BARRIERS IN THE QUALITY OF PRODUCTION
}

doi: 10.2478/cqpi-2019-0001

Date of submission of the article to the Editor: 01/05/2019

Date of acceptance of the article by the Editor: 23/05/2019

Małgorzata Suchacka ${ }^{1}$ - orcid id: 0000-0002-3769-5892

Nicole Horáková ${ }^{2}$ - orcid id: 0000- 0002-1075-053X

1 University of Silesia in Katowice, Poland

2 University of Ostrava, Czech Republic

Abstract: In this article is drawn attention to the social aspects of improving the quality of production. The relationship between the development of technology and society is still underappreciated. There is a vital need to make technical managers aware of the rules governing interpersonal relationships. This theoretical article aims to bring the basic concepts of social sciences closer to recipients focused on constant improvement of the production quality. The essence of the work process is primarily the fact that it is done by a human being and mostly in a group of people. This is related to the consequences of sociological nature to which managers do not pay enough attention. Instead of focusing on social and interpersonal problems they are dealing with organizational issues. The conclusion of consideration leads to underlining the need for constant improvement - manager training in social engineering principles.

Keywords: quality of production, organizational culture, manager, social relationships

\section{INTRODUCTION}

Quality in production has been the subject of many research and scientific analysis for years and the key meaning of the human factor is very often emphasized. Unfortunately, it is still undervalued, which results from the vast complexity of human nature. Often one also forgets that man is a social being and concern for the quality of production cannot be reduced to taking into account the psychological aspects of human work. A sensible manager will study the relationship between technology development and change in society itself. This requires an in-depth approach and sociological sensitivity.

The article will aim to present social conditions influencing the quality of production and to draw attention to the need for an interdisciplinary approach to the issue of production quality. The base will be an overview of the selected sociological literature indicating the key topics that are present in many studies. The article will cover, among others, the issues of technology development and relations with the public, the importance of the role of managers, organisational culture also in terms of gender and interpersonal conflicts. 
These issues were presented against the background of selected authors' views and definitions in the field of social sciences. The article uses the method of critical analysis and synthesis of opinions of other authors and deduction inference. Reflections will have a theoretical character, while the scope of analyses based on literature studies on selected concepts must be significantly limited. The practical dimension of the deliberations will be to create a base of more important topics for further empirical research.

\section{THE RELATIONSHIP BETWEEN THE DEVELOPMENT OF TECHNOLOGY AND SOCIETY}

Since the beginning of the Industrial Revolution in the early 19th century, the relationship between technology and society is one of the main issues of sociological research. One of the first theoreticians who raised the question of mutual dependence between society and technology and asked for the impact new technologies will have on the social bounds was Karl Marx. He and his co-author Friedrich Engels were convinced that the superstructure of a society is determined by the modes of production. The term "modes of production" includes in Marx' opinion the production forces as the technical inventions and the relations of production which are the social structures that regulate the relationship between humans in the production of goods. In Marx's analysis are "technology and society (...) intimately, intricately, and reciprocally connected" (Bauchspies, et all, 2006). Marx pointed out that the social relationships in societies are shaped by economic structures which are strongly influenced by the technical development. The concept of technological determinism is very closely connected with this idea of Karl Marx and links different approaches which describe the relationship of "technology" and "society". The most common claim understands technology as an autonomous issue which shapes social relations (Kline, 2015).

New approaches explaining the relationship between technology and society came up in the 70ties of the last century. In this frame e.g. Braverman pointed out that technological innovation "is not driven by its own internal logic but is shaped by the social and economic characteristics of capitalist societies" (McLoughlin, 2002) to generate profits by controlling work performance. The Labour process theory starts from the assumption that technological inventions were made with the aim to increase productivity and to better control the employee behavior by the management. The first attempts in this direction were made by Henry Ford by inventing the line production system to set up mass production of cars. In post-Fordism era these mechanisms are - with the help of new virtual technology - even more sophisticated as the followers of the Labour process theory argue. This approach was criticized by different researchers pointing out that technical innovations were not made by management and previously served to deskill the working process (McLoughlin, 2002) not to control it. The Social Shaping of Technology approach outlined in 1985 by Mackenzie and Wajcman points out that technology is not an independent factor but "the characteristics of a society play a major part in deciding which technologies are adopted" (Mackenzie, Wajcman, 1985). Or as Webster formulates: "a range of social, cultural, economic, political and organizational factors, in addition to pre-existing technological arrangements, have been shown to shape technologies" (Webster, 1995). The success story of the automobile and its development process at the beginning of the 20th century until today is an example to strength the "social shaping 
of technology" approach because there are better, cheaper, greener and more efficient forms of transportation than the car which still dominates mobility despite all its disadvantages (Bauchspies, et all, 2006) It can be concluded that "it is not some sort of simple "best" technology that always wins. It is a matter of the cultural ideals, economic relations, and social power relations that define what counts as best, for whom, and for whose preferred activities and values" (Bauchspies, et all, 2006).

It is also important to realize that "the same technology can have very different 'effects' in different situations" (Mackenzie, Wajcman, 1995). Technical inventions can be used in a positive way to develop the society or to destroy it. (Bauchspies, Croissant, Revisto, 2006). Thus, technology is not neutral in the beginning but can be used flexibly and can be redefined by the users for their needs To this point also refer Mackenzie and Wajcman when claiming that the idea of technology triggering straightforwardly "social effects" is too simple (Mackenzie, Wajcman, 1995). To understand the complex impacts technology can have on society the overall dynamics in the different societies should be taken into account. On the question what shapes technology Mackenzie/Wajcman give a clear answer: society is not only affected somehow by technology but is primarily shaping it. They argue that science does not stand outside society but "is (sic!) affected at the most profound level by the society in which it is conducted" (Mackenzie, Wajcman, 1995). Society has not only impact on the valuation and the direction of development of science but it has also influence on scientific theories and if they are considered as true or false by the scientists. From this point of view even the level of fact which is in generally considered as objective and neutral must be seen as social: "different groups of scientists in different circumstances have been shown to have produced radically different 'facts" (Mackenzie/Wajcman, 1995).

Another common approach used for describing the relationship between technology and society is the so called Social Construction of Technology theory (SCOT) worked out by Bijker in 1984. This approach represents a "multidirectional" model to explain the evolution of technical innovation. This is in clear contrast to the linear model, which is often used to explain the evolutionary history of a product (Bijker, Pinch, 2012). For the future product relevant social groups (here institutions as the military or some specific industrial company and organized or unorganized groups of individuals) are shaping through competition, conflict and interaction the development of the technology. The SCOT approach believes that a problem can have multiple solutions, but only one solution will prevail and become mass-marketable. This is in most cases the solution that satisfies the ideas and claims of several relevant social groups regarding the product. (Bijker, Pinch, 2012). The SCOT approach differs from the "social shaping of technology" approach in a lot of aspects. The most important one is that SCOT "attributes much more malleability to technology, refusing to attribute to the 'technical' any hard content at all" (Webster, 1995).

Finally, technology is not only shaped by differing social groups and by political class interests but gender relations play also a crucial role in shaping the relationship between technology and society. Not only the effects of technology can be interpreted as a function of the patriarchal relationships (special "women" skills in jobs) but also the "content of technology itself is considered to be gendered" (McLaughlin, 2002). 


\section{THE ROLE OF MANAGERS AS A LEADER AND AUTHORITY}

A key factor in the concern for the quality of production is the approach to the work of managers. The position is held by authority, which has on the one hand a formal nature resulting from the organisational legitimacy and on the other hand, it should be supported by an informal authority obtained on the basis of the employees' respect.

Today's manager is looking for opportunities for continuous learning: Bearing in mind the quality standards, which determines, verifies and corrects the norms, values and behaviours adopted by the institution on an ongoing basis, managers striving for optimal efficiency at work and they becoming simultaneously more and more responsible for their actions and the result of subordinates' work. They are also increasingly sensitised to employee issues and intercultural problems by supporting, inspiring the development of co-workers and subordinates (Banaszek 2006, Kuc 2004, Szczupaczyński 1998, Żukowski 2005).

Non-negligible is the need to deepen the knowledge of the basics of the functioning of power and the rules of its exercise. Sources of different ways of interacting with subordinates have already been described in the literature and can be used effectively to manage human resources for the sake of production quality (Webber Ross 1996). The authority can, therefore, be based on force, rewarding, legitimate, charismatic relations. It can also be expert or representative body related to delegating powers up.

Depending on the subordinate's hierarchy of needs, other elements will be based on the process of influence. The basis are six main reasons for people's reactions: fear hope, tradition, blind faith, rational faith, reasonable thinking and joint arrangements. Particularly noteworthy is the exercise of power through persuasion and rational belief. It results from an understanding of the need for specific actions and consent to them. If the leader rationally explained his actions, devoting the right amount of time to it, as a consequence he persuades the subordinates to their rational actions.

By proceeding in this way, he expressed his appreciation towards employees, making them understand that he treated them as worthy of specific treatments and explaining the decisions taken. In this case, persuasion will be more effective if the superior is credible in terms of specialist knowledge and reliability, his views are in line with subordinates' opinions, the information is elitist for the privileged, and the image of the superior is accepted by the listeners (Webber, 1996).

This procedure requires in the context of quality of work, competence, commitment and independence from co-workers. It matches the management style to specific situational conditions. The theoretical studies show the relativisation of styles of management.

Democratic, autocratic and passive approach is the most popular classification of management styles, also related to the care for quality (Kieżun 1997). Among many other examples, it is difficult to find a management model that decides in a clear way about the efficiency of the supervisor's work. In this aspect, the choice of the management style may be adequate or inadequate to the environment and working conditions. The effectiveness of the management style applied by the supervisor does not depend only on the manager's focus on tasks and on employees. Many of the personal qualities of the supervisor and subordinates as well as situational factors decide and force the use of an adequate style of team management. Among the situational factors predominate are time constraints, team integrity, company tradition, 
and security of task execution. These conditions create a working atmosphere for which the manager is responsible.

An important component of the team's work atmosphere is the awareness of understanding the procedures and rules in force and the acceptance of superiors according to their competences and preparation (Kożusznik, 2010). This is particularly important in the case of procedures for maintaining the quality of work performed. Evaluation of working performance is a significant tool for creating working atmosphere. Using this kind of tool, the manager has directly influence on the working performance of his subordinated workers. The coaching and feedback-culture shapes directly the relationships inside the team and shows the strength or the weak sides of the manager. (Krawczyk-Bryłka, 2013).

The manager has another very special role in the organizational landscape of the company - it is his role in the field of social responsibility. It boils down to the real impact of the company manager on the qualitative conditions of the development of the staff - among others, management of employees' talents and the practical dimension of understanding corporate social responsibility (CSR) (Karaszewski, Lis, 2014). Identifying relations between these areas, their identification and the identification of their most important features is an element of creative shaping of the organizational culture and the course of interpersonal conflicts.

\section{SELECTED SOCIOLOGICAL CONCEPTS IN THE CONTEXT OF IMPROVING THE QUALITY OF PRODUCTION}

The sociological conditions of production quality have a multidimensional character and a complicated nature. Some of them are phenomena, others have the structure of long-term processes shaping people's approach to work - including the quality of production. Certainly, however, the issues of organizational culture and interpersonal conflicts appear as the first plan as phenomena integrally connected and mutually conditioning.

\subsection{Organizational culture and the quality of production}

The term of culture in social sciences is very wide spread and not easy to define. According to organizations, culture involves the values and behaviors that built the unique environment of a company. The organizational (or corporate) culture has impact on the way employees interact, how innovations and changes are incorporated, knowledge is created and shared among the organizational members (communication strategy). These accepted (or not accepted) values, beliefs and principles shared by all employees are influenced and built by many components such as history of the organization, technology, management style and national culture. The organizational culture is not only visible in abstract items like values, norms, systems and visions but also in concrete behavior (interaction with costumers and stakeholders), symbols, language and habits (Schein, 2010; Schultz et all, 2012). The first organization theorist, the British sociologist Elliott Jaques inspired many organizational theoreticians worldwide. In the studies from the 1970ties, the question of how organizational culture can be measured came to the fore and an answer has been given by the Dutch organization theorist Geert Hofstede who explored the national influences on organizational culture. Hofstede observed five (later six) cultural dimensions (power distance, uncertainty avoidance, individualism versus 
collectivism, feminine versus masculine, long term/short term orientation and indulgence versus self-restraint) by analysing data of IBM workers (Hofstede, 2009) which cover different behavioural approaches of employees and affect the organizational culture. Hofstede's research was complemented by the work of the American social psychologist Edgar Schein. Schein stressed that a set of basic assumptions forms the core culture of an organization. To these basic assumptions belong artefacts as visible part of the organizational culture, values as social principles, goals and standards and on the highest, most unconscious level are assumptions. (Hatch, 2013). The different approaches developed from the anthropological perspective show that organizations, their development and their attitude towards technological innovation is not a singular reaction of the organization, but it is integrated into the social context of the society, which influences the organizational culture in a lasting way.

\subsection{Interpersonal conflicts and the quality of production}

Technological progress and meticulous quality control create new situations that carry various types of threats to employees. Subjective perception of the techniques used and the provision of security systems gives rise to the necessity of cooperation primarily of the leaders, but also of all employees during the implementation of any changes in the broadly understood culture of the organization. Conflicts between people are always a symptom of pathological and disorganising phenomena. They can be individual, group and organisational (Folger, et all, 2016).

The source of such disorganisation, which ultimately has an impact on the quality of production and services, are disputes arising from the lack of enforcement of the objectives and tasks of the workplace, ambiguities in the division of labour, the roles system, inaccuracies in the communication system. Conflicts are a situation that is not solved or resolved contrary to the expectations of the parties that assume conflicting interests. They are playing an important role when opposing values collide.

Introduced new technologies may cause different conflicts and require precise control and training of employees. Failure to notice the importance of quality in the production process and failure to apply appropriate procedures may lead to increasing frustration among employees. In their essence, conflicts manifest themselves in such employee behavior as rebellion, strike, disregarding regulations, instructions, discipline or -in the quality of work. These situations can be overt and hidden, rational and irrational, creative and destructive. Conflicts are inevitable, but the main assumption of their solution is the benefit of all interested parties.

A well-managed conflict - especially around the quality of production - stimulates better ideas, forces the involved groups to search for new solutions, stimulates interest and creativity. It can be assumed that conflicts in enterprises are born, among others, due to poorly understood concern for the quality of production and. In this case, the effective and integrated supply chain, material management, maintenance of technological infrastructure and reliability of technical facilities are of great importance 


\section{CONCLUSIONS - RECOMMENDATION CONCERNING IMPROVING THE QUALITY OF PRODUCTION}

It is difficult to develop comprehensive recommendations regarding the inclusion of social factors in the process of control and ongoing care for the quality of production. Literature studies suggest many threads that should be taken into account. Certainly, issues such as organizational culture, interpersonal conflicts, introducing changes and managerial responsibility are topics that are too weakly emphasized at the stage of educating future leaders. This is a fundamental recommendation that could be suggested on the basis of the materials analyzed. An in-depth knowledge of human nature in its social environment requires patience and an extremely positive approach to full understanding, which will translate into the capital of trust in the company. This is a category for separate scientific theoretical analyses and interesting empirical approaches.

\section{ACKNOWLEDGEMENTS}

This paper has been financially supported by University of Ostrava, Institutional Development Project (IRP) No. 201819 Social and Cultural Mechanisms of In- and Exclusion: a Comparative Perspective.

\section{REFERENCES}

Banaszek S., 2006. Menedżerowie w strukturze społecznej, Wyższa Szkoła Komunikacji i Zarządzania, Poznań.

Bauchspies, W. K., Croissant, J., Revisto, S., 2006. Science, Technology, and Society: A Sociological Approach. Blackwell Publishing Oxford.

Bijker, W.E, Hughes, T. P., Pinch, 2012. The Social Construction of Technological Systems. New Directions in the Sociology and History of Technology. The MIT Press, Cambridge, Massachusetts, London.

Folger, Joseph P.; Poole, Marshall Scott; Stutman, Randall K., 2016. Working Through Conflict: Strategies for Relationships, Groups, and Organizations, Seventh edition. Routledge London.

Hatch, M.J., 2013. Organization Theory. Modern, symbolic and postmodern perspectives, third ed. Oxford University Press, Oxford.

Hofstede, G., 2009. Dimensionalizing Cultures: The Hofstede Model in Context. Online Readings in Psychology and Culture.

Hofstede, G., Hofstede, G. J., Minkov, M., 2010. Cultures and Organizations. Software of the Mind. McGrow-Hill, New York, Chicago.

Karaszewski R. Lis, A., Przywództwo i CSR w kontekście pozytywnego potencjału organizacji, Marketing i Rynek, nr 5/ 2014.

Kieżun W., 1997. Sprawne zarządzanie organizacją, Wydawnictwo Szkoła Główna Handlowa, Warszawa.

Kline, R.R., 2015. Technical Determinism. International Encyclopedia of the Social \& Behavioral Sciences (Wright, J. D. ed.), second ed. Elsevier, Amsterdam. 109 112. DOI: 10.1016/B978-0-08-097086-8.85034-5

Kożusznik B., 2010. Kluczowa rola psychologii we wspieraniu $i$ w stymulowaniu innowacyjności, in: Psychologiczne uwarunkowania innowacyjności, (ed. Z. Spendel), Wydawnictwo Uniwersytetu Śląskiego, Katowice. 
Krawczyk-Bryłka B., 2013. Wymiary klimatu pracy zespołowej, Przedsiębiorczość i Zarządzanie, t. XIV, z. 13, cz. I.

Kuc B.R., 2004. Od zarządzania do przywództwa, Wydawnictwa Menedżerskie PTM, Warszawa.

Mackenzie, D., Wajcman, J., 1985. The Social Shaping of Technology. Open University Press.

McLoughlin, I., 2002. Creative Technological Change. The Shaping of Technology and Organizations, second ed. Routledge, London, New York.

Schein, E. H., 2010. Organizational Culture and Leadership. Fourth ed., Jossey-Bass, San Francisco.

Schultz, M., Maguire, S., Langley, A., Tsoukas, H., 2012. Perspectives on Process Organization Studies: Constructing Identity in and around Organizations. Oxford University Press, Oxford.

Szczupaczyński J., 1998. Anatomia zarządzania organizacją, Międzynarodowa Szkoła Menedżerow, Warszawa.

Webber Ross A., 1996, Zasady zarządzania organizacjami, Państwowe Wydawnictwo Ekonomiczne, Warszawa.

Webster, J., 1995. The Difficult Relationship between Technology and Society. Work, Employment \& Society. Vol. 9, No. 4, $797-810$.

Żukowski P., 2005. Wymiar osobowy $i$ etyczny współczesnego menedżera, in: Współczesne problemy edukacji, pracy i zatrudnienia pracowników (ed. B. Pietrulewicz), Uniwersytet Zielonogórski, Zielona Góra. 